\title{
OSMOTIC FACTORS INFLUENCING THE FORMATION OF ASCITES IN PATIENTS WITH CIRRHOSIS OF THE LIVER
}

\author{
By HAROLD MANKIN AND ALICE LOWELL \\ (From the Research Service, First [Columbia] Division, Goldwater Memorial Hospital, \\ and the Department of Medicine, Columbia University, New York City)
}

(Received for publication July 19, 1947)

According to present concepts, the ascites that occurs in patients with cirrhosis of the liver is formed by transudation from the plasma into the peritoneal cavity through the walls of the capillaries of the portal system. A ready explanation for this transudation has been at hand, based upon the hypothesis originally proposed by Starling (1 to 3 ) that interchange of fluid between blood and tissue spaces is controlled by the balance between capillary blood pressure and osmotic pressure of plasma proteins. In patients with cirrhosis and ascites the portal venous pressure is high (4); the serum albumin concentration ( 5 to 7 ) and the serum colloid osmotic pressure (8) are low. The observations of Post and Patek (7) have suggested that the presence or absence of ascites in patients with cirrhosis of the liver is determined chiefly by the serum albumin level.

Recent observations have thrown doubt upon this concept $(9,10)$. In the course of an investigation of the effects of intravenous injection of concentrated human serum albumin in patients with cirrhosis and ascites (10) it was observed that elevation of the colloid osmotic pressure of the plasma to normal levels for periods of 2 weeks did not decrease the rate of ascites formation. There occurred instead a marked increase in the rate of diffusion of albumin from the plasma into the ascitic fluid and a rise in the colloid osmotic pressure of the ascitic fluid which paralleled that of the plasma.

Because these observations seemed inconsistent with the accepted concepts of the mechanism of ascites formation, the present studies were undertaken in order $(a)$ to determine whether or not the formation of ascites in patients with cirrhosis of the liver is controlled by osmotic factors, in accordance with the Starling hypothesis, and (b) to evaluate the role of the diffusion of plasma proteins into the peritoneal cavity.

According to the Starling hypothesis, the flow of fluid across the portal capillary membrane is controlled by the balance of hydrostatic and colloid osmotic pressures on both sides of the membrane (11), such that at equilibrium:

portal capillary pressure minus intra-abdominal hydrostatic pressure $=$ plasma colloid osmotic pressure minus ascitic colloid osmotic pressure.

Disturbance of the osmotic balance by alteration of any of these factors should produce corresponding changes in the rate and direction of flow.

In order to test the validity of this hypothesis, direct measurements were made of (1) the plasma colloid osmotic pressure, (2) ascitic colloid osmotic pressure, (3) the intra-abdominal hydrostatic pressure, and (4) the ascitic fluid volume, both in the unmodified course of the formation and loss of ascites, and after experimental alteration of one of the osmotic factors. The experimental elevation of plasma colloid osmotic pressure was effected by $(a)$ mercupurin diuresis and $(b)$ intravenous injection of concentrated human serum albumin. Plasma colloid osmotic pressure was decreased by the oral administration of physiological saline solution. Ascitic colloid osmotic pressure was decreased by the intraperitoneal injection of salt solution. Intra-abdominal hydrostatic pressure was increased by the accumulation of ascites and decreased by abdominal paracentesis. The net transfer of albumin was calculated from the increase or decrease of total ascitic albumin (ascitic albumin concentration $\times$ ascitic volume).

\section{METHODS}

The subjects of these studies were 10 patients with cirrhosis of the liver receiving treatment on the wards of the Columbia Research Service at the Goldwater Memorial Hospital. The clinical diagnoses were confirmed by liver biopsy ( 8 cases), laparotomy (1 case), or autopsy (1 case). Nine cases were of the Laennec type; 1 (patient N.) was diagnosed as post-necrotic cirrhosis. The therapeutic regimen consisted, in general, of the nutritious diet and supplements rich in vitamin B complex described by Patek and Post (12). 


\section{Colloid osmotic pressure}

For the determination of colloid osmotic pressure an Hepp osmometer (13) was used. In this apparatus a 2 cc. sample of serum or ascitic fluid is brought into equilibrium at room temperature with a protein-free "reference" salt solution across a semi-permeable collodion membrane. The colloid osmotic pressure is directly measured as the negative pressure upon the "reference" solution which prevents the motion of a capillary meniscus. The equilibrium is rapidly established (usually within 5 minutes), without significant volume change in the sample and before appreciable loss of carbon dioxide. The reproducibility of successive measurements was found to be $\pm 1 \mathrm{~mm}$. $\mathrm{H}_{2} \mathrm{O}$ (118 duplicate measurements). Comparison of measurements upon the same specimen of serum before and after storage in the refrigerator for several days, and with change of membrane, showed an average difference of $7 \mathrm{~mm} . \mathrm{H}_{2} \mathrm{O}$ (40 duplicate measurements).

The Hepp osmometer and directions for its use were furnished through the kindness of Dr. Bernard Davis. The composition of the "reference" solution was: $0.14 \mathrm{M}$ $\mathrm{NaCl}, 0.025 \mathrm{M} \mathrm{NaHCO}$. Collodion membranes of suitable permeability were prepared by the method of Pierce (14) : 15 cc. of a 2 per cent Parlodion solution in 50 per cent absolute alcohol-50 per cent ether, containing 10.0 volumes per cent ethylene glycol, were poured onto a mercury surface in an evaporating dish of $9.5 \mathrm{~cm}$. diameter, and evaporated to complete dryness ( 24 hours) in a moisture-free atmosphere. The membranes were washed for 48 hours in running tap water, and stored in distilled water.

Blood samples were taken under standardized conditions in order to minimize the effects of venous stasis $(15,16)$ and of postural variation (17 to 19). The patients were kept flat in bed for at least 2 hours before the taking of blood samples. Venipuncture was accomplished as rapidly as possible after the tourniquet application, usually within 1 minute. Under these conditions the average diurnal variation of serum colloid osmotic pressure in a given patient was \pm 2 per cent (14 samples). On successive days the average variation was \pm 4 per cent ( 59 samples). Specimens of ascitic fluid were obtained without difficulty or complication by inserting a No. 20 needle through the anterior abdominal wall after local infiltration with novocaine.

\section{Ascitic fluid volume}

For the measurement of the volume of ascitic fluid a procedure was devised based upon the dye dilution method for the determination of plasma volume (20). The dyes Evans blue (T-1824) and brilliant vital red were found suitable. After an ascitic fluid "blank" was withdrawn, a measured quantity of dye was injected intraperitoneally. Vigorous ballottement of the abdomen with several changes of position produced apparently uniform distribution of the dye in $1 / 2$ hour. A second specimen of ascitic fluid, obtained $1 / 2$ to 1 hour after dye injection, was compared with the blank in a spectrophotometer and the volume calculated. Following intraperitoneal injection of the dye there was no significant decrease in dye concentration in the ascitic fluid within several hours. The dye was first detected in the plasma 24 to 48 hours after intraperitoneal injection.

In order to test the accuracy of the method, dye-volume determinations were performed before and after removal of 4 to 7 liters of fluid from the peritoneal cavity ( 5 comparisons). The average difference, regardless of sign, between the calculated volume differences and the actual volumes removed was $375 \mathrm{cc}$.

\section{Intraperitoneal hydrostatic pressure}

As a possible index to the effective hydrostatic pressure in the tissues surrounding the portal capillaries, measurements were made of the intraperitoneal hydrostatic pressure under the following standard conditions. With the patient flat on his back, a No. 20 needle was inserted through the lateral abdominal wall at a standard level halfway from back to front. The ascitic fluid was allowed to seek a stable level in an L-tube manometer.

Readings were immediately reproducible within $5 \mathrm{~mm}$. $\mathrm{H}_{2} \mathrm{O}$. In the same patient, in 2 successive periods of ascites accumulation, at equal body weights, manometric values agreed within $10 \mathrm{~mm}$. $\mathrm{H}_{2} \mathrm{O}$.

\section{RESULTS}

I. Observations upon the unmodified course of ascites formation

\section{A. The accumulation of ascites between abdominal paracenteses}

Repeated cycles of accumulation of ascites between abdominal paracenteses were studied in patients whose ascites formation was at an approximately steady state. The object was to determine what influence the accumulation of ascites has upon the balance between the osmotic forces.

Ascitic fluid volumes were measured at intervals through 10 periods of ascites accumulation in 4 patients. The average interval between abdominal paracenteses was 12 days. The average ascitic volume at paracentesis was 8 liters. The ascitic volume increased rapidly during the first 3 days post-paracentesis; thereafter the rate of increase was uniform. The intraperitoneal hydrostatic pressure increased with the accumulation of ascites from an initial value of about $125 \mathrm{~mm} . \mathrm{H}_{2} \mathrm{O}$ to about $225 \mathrm{~mm} . \mathrm{H}_{2} \mathrm{O}$ at the time of paracentesis ( 2 periods in 1 patient). The colloid osmotic pressures of the serum and ascitic fluid (15 periods in 6 patients) were approximately constant throughout each period (Figure 1). 


\section{COLLOID OSMOTIC PRESSURE OF \\ SERUM AND ASCITIC FLUID WITH ACCUMULATION OF ASCITES}

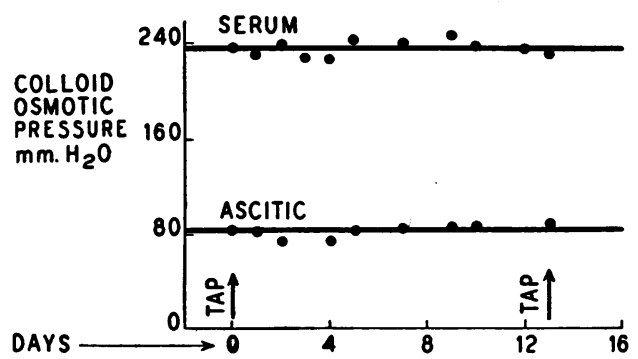

Fig. 1. Colloid Osmotic Pressure of Serum and Ascitic Fluid in the Course of Ascites Accumulation (Patient D.)

The constancy of the colloid osmotic pressures of the plasma and ascitic fluid in the face of a nearly 2 -fold increase in the intra-abdominal hydrostatic pressure suggests that either (1) transudation into the peritoneal cavity is independent of the intra-abdominal pressure in this range or (2) some type of equilibrium is maintained between the hydrostatic and colloid osmotic pressures as the ascites accumulates. In the latter case, the findings suggest that increase in intraabdominal hydrostatic pressure in the course of ascites accumulation is balanced by a concomitant increase in portal capillary pressure.

\section{B. Long term studies of the formation and spon- taneous absorption of ascites}

The measurements of colloid osmotic pressure, described above in patients at a steady state, were extended over longer periods of time in order to determine the relation between the colloid osmotic pressures of the plasma and ascitic fluid in the course of (1) spontaneous variation in the plasma colloid osmotic pressure and (2) spontaneous absorption of ascites.

Three patients were studied through periods of 4 months to 1 year. Changes in serum colloid osmotic pressure (up to $120 \mathrm{~mm} . \mathrm{H}_{2} \mathrm{O}$ ) were accompanied by parallel changes in ascitic colloid osmotic pressure, so that the difference between the colloid osmotic pressures of the serum and ascitic fluid remained approximately constant $( \pm 10 \mathrm{~mm}$. $\mathrm{H}_{2} \mathrm{O}$ ) in each patient throughout the periods of study.
In 2 of these patients the studies extended through periods both of formation and spontaneous loss of ascites. Loss of ascites in these cases was gradual over 2 to 3 months. Associated with the diuresis there was a gradual elevation of the serum colloid osmotic pressure from levels of 200 to 240 $\mathrm{mm} . \mathrm{H}_{2} \mathrm{O}$ to levels of 270 to $300 \mathrm{~mm} . \mathrm{H}_{2} \mathrm{O}$. The colloid osmotic pressure of the ascitic fluid increased with that of the serum. Associated with the transition from formation to absorption of ascites there was no change in the relation between the colloid osmotic pressures of the serum and ascitic fluid.

These observations suggest that in each patient a constant difference between the colloid osmotic pressures of the plasma and ascitic fluid is maintained through equilibrium with a constant effective hydrostatic pressure in the portal system. This phenomenon suggests that there is no significant decrease in effective portal pressure during spontaneous loss of ascites.

\section{Experimental alteration of the osmotic factors}

In order to test the hypothesis that approximate equilibrium exists between the plasma and ascitic fluid, the colloid osmotic pressures of the plasma and ascitic fluid were experimentally altered by the following measures: (A) mercupurin diuresis, (B) oral administration of isotonic sodium chloride solution, (C) intraperitoneal injection of isotonic sodium chloride solution, and (D) intravenous injection of concentrated human serum albumin.

\section{A. Mercupurin diuresis}

Mercupurin was used as a means of increasing the colloid osmotic pressure of the plasma. Previous authors have reported elevation of the serum colloid osmotic pressure (21) or of the serum protein concentration (22) in association with organic mercurial diuresis, presumably through the mechanism of hemoconcentration. Mercurial diuresis without apparent hemoconcentration has been observed $(22,23,24)$. In the present studies, significant elevation of serum colloid osmotic pressure occurred when the urinary output exceeded the control values by $2500 \mathrm{cc}$. (4 experiments). The colloid osmotic pressure rose 10 to $20 \mathrm{~mm} . \mathrm{H}_{2} \mathrm{O}, 4$ hours after intravenous injection 

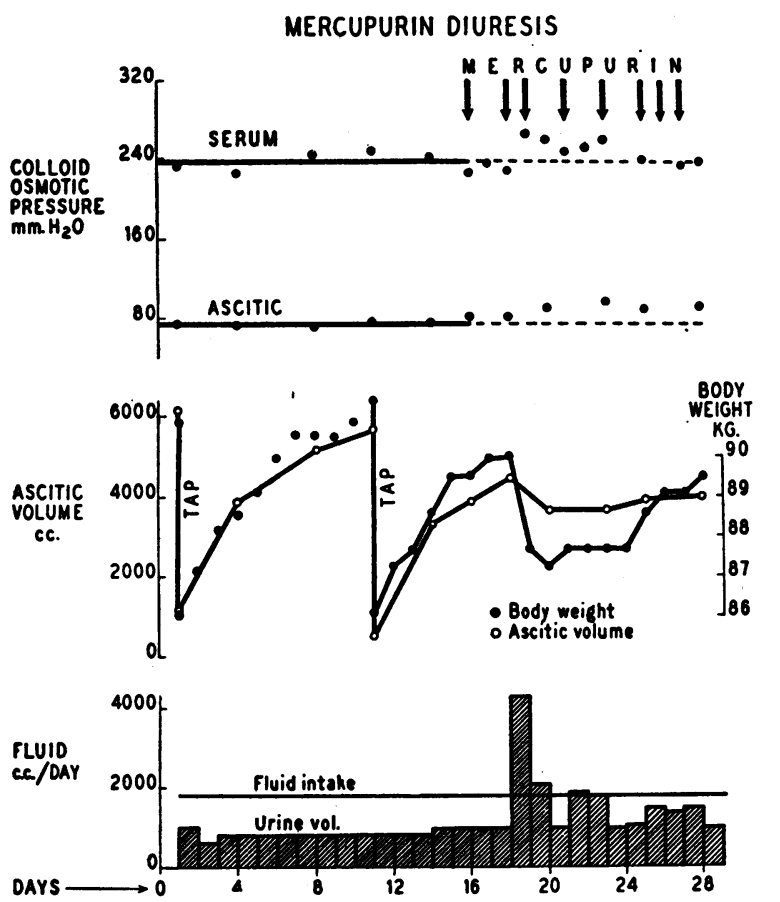

Fig. 2. EfFects of Repeated Intravenous InJections of Mercupurin (Patient G.)

Mercupurin injections $(2 \mathrm{cc}$.) are indicated by arrows at the top of the figure.

of 2 cc. mercupurin, reached a peak increase of 30 to $40 \mathrm{~mm}$. by the 8th hour, and then fell about $15 \mathrm{~mm} . \mathrm{H}_{2} \mathrm{O}$ in the next 16 hours. In 4 cases where excess urinary output was less than 2000 cc., no significant elevation of serum colloid osmotic pressure was observed.

The effects of repeated daily intravenous injections of mercupurin ( 2 cc.) were studied in 3 experiments upon 2 patients through periods of 5 to 11 days (Figure 2). The diuretic response was variable, with extremes of 0 to $3500 \mathrm{cc}$. per 24 hours. The serum colloid osmotic pressure, measured 24 hours after injection, increased only slightly during the period of mercupurin injections. The body weight and ascitic volume decreased following diuresis. The colloid osmotic pressure of the ascitic fluid increased by about the same increment as that of the serum, with a lag of 24 to 48 hours.

\section{B. Oral administration of isotonic sodium chloride solution}

In the present investigation, salt solution was administered in order to effect hemodilution and decrease of the plasma colloid osmotic pressure $(25,26)$. Two patients were given orally, in addition to their usual salt-poor regimen, $2000 \mathrm{cc}$. of 0.9 per cent sodium chloride daily for 3 successive days (Figure 3 ). The serum colloid osmotic pressure fell progressively. The maximum decrease was $40 \mathrm{~mm} . \mathrm{H}_{2} \mathrm{O}$. The body weight and ascitic volume increased precipitously by comparison with the control periods. The excess ascitic fluid represented approximately $1 / 2$ the increase in body weight. The colloid osmotic pressure of the ascitic fluid decreased with that of the serum. The maximum decrease was $30 \mathrm{~mm} . \mathrm{H}_{2} \mathrm{O}$.

\section{Intraperitoneal injection of isotonic sodium chloride solution}

In order to study the effects of decrease of the colloid osmotic pressure of the ascitic fluid, the ascitic fluid was diluted by withdrawing ascitic fluid from the peritoneal cavity and instilling an equal volume of isotonic sodium chloride solution (2 cases). Strict precautions were exercised

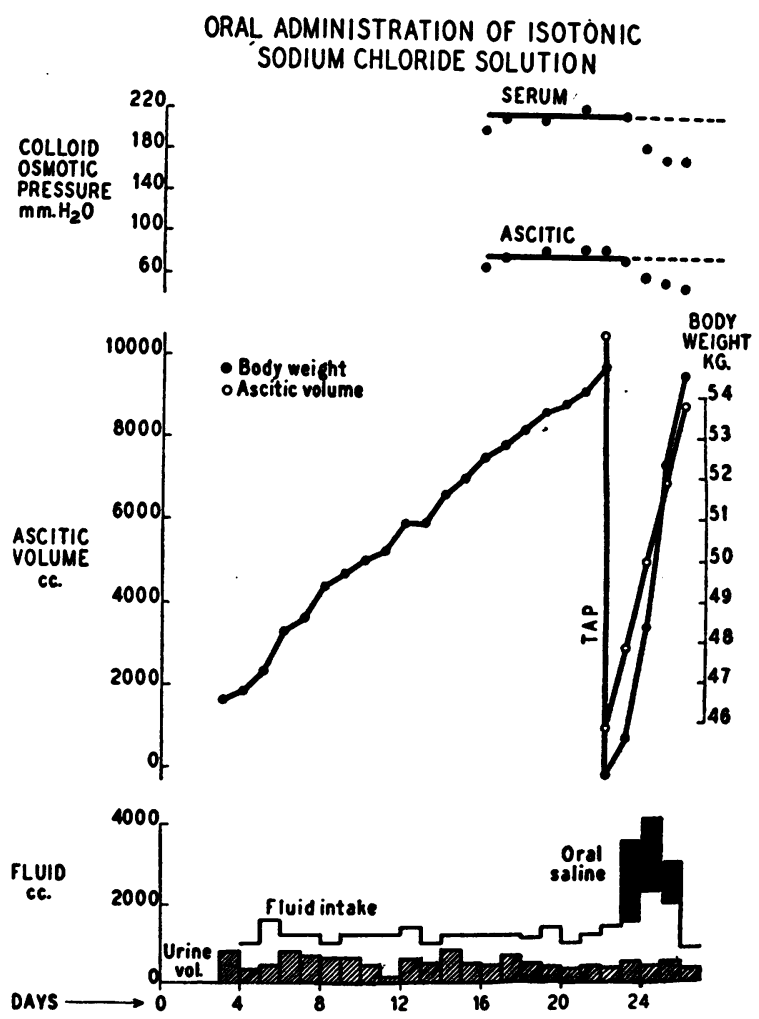

Fig. 3. Oral Administration of Isotonic Sodium Chloride Solution (Patient N.) 
against bacterial or chemical inflammation of the peritoneum.

The results of repeated daily intraperitoneal instillations of salt solution are shown in Figure 4. The colloid osmotic pressure of the ascitic fluid was decreased step-wise to a minimum value 80 mm. $\mathrm{H}_{2} \mathrm{O}$ below the preinjection level. In the 6 days following the last intraperitoneal injection, the ascitic colloid osmotic pressure rose to a level $50 \mathrm{~mm} . \mathrm{H}_{2} \mathrm{O}$ below the control level. The rate of ascites formation showed a slight decrease. The serum colloid osmotic pressure decreased gradually during the period of dilution of the assitic fluid. The final decrease $\left(50 \mathrm{~mm} . \mathrm{H}_{2} \mathrm{O}\right)$ was approximately the same as that of the colloid osmotic pressure of the ascitic fluid.

The decrease in plasma colloid osmotic pressure was due, at least in part, to an increased transfer of protein from plasma to ascitic fluid. During the 10-day control period the calculated total ascitic fluid albumin increased 6 grams per day. During the first 8 days of ascitic fluid dilution, the calculated average daily increase was 10 grams. Since there were neither physical signs nor cytological evidence of peritoneal inflammation, it

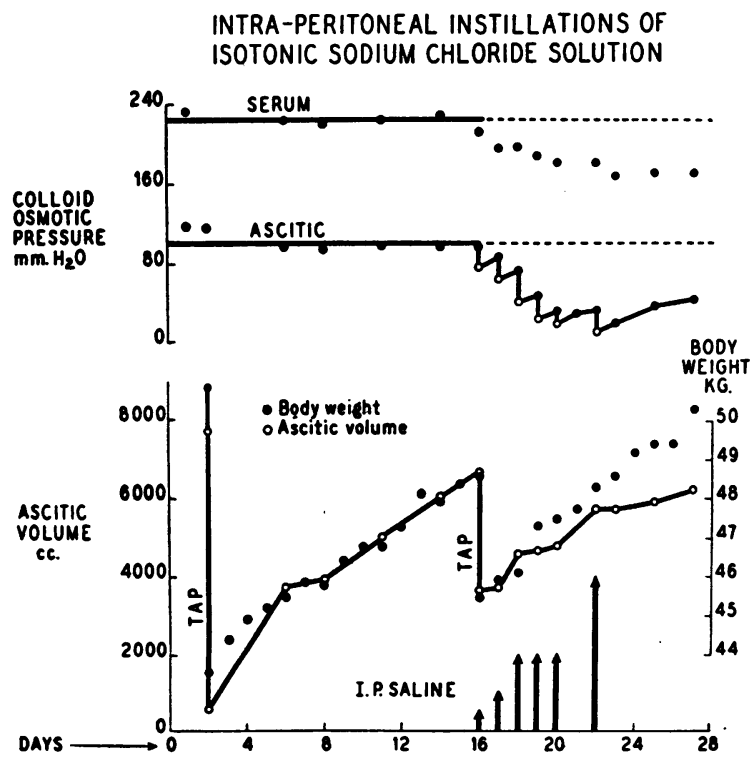

Fig. 4. Effects of Repeated Dilution of Ascitic Fluid by Intraperitoneal Instillations of Isotonic Sodium Chloride Solution (Patient N.)

Ascitic fluid was withdrawn and an equal volume of salt solution substituted. Arrows represent volumes of 500 cc., 1000 cc., 2000 cc., and $4000 \mathrm{cc}$.

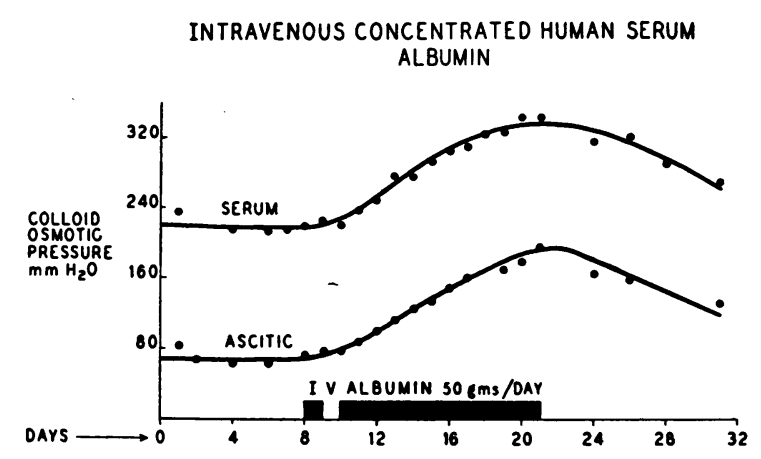

Fig. 5. Effects of Daily Intravenous Injection of Concentrated Human Serum Albumin (Patient N.)

may be postulated that the diffusion of protein was increased as a function of an increased protein concentration gradient between the plasma and the ascitic fluid.

\section{Intravenous injection of concentrated human serum albumin}

The effects of intravenous administration of concentrated albumin are described in detail in a separate report (10). From the point of view of the present study, the results may be summarized as follows:

Three patients received daily intravenous injections of 50 grams of concentrated human serum albumin (containing $0.3 \mathrm{M} \mathrm{NaCl}$ ) for periods of 13 to 16 days. The serum colloid osmotic pressure increased during the period of albumin therapy and then decreased (Figure 5). The values reached normal levels (above $300 \mathrm{~mm} . \mathrm{H}_{2} \mathrm{O}$ ) by the 7th day of injection and remained in the normal range for 2 weeks. The colloid osmotic pressure of the ascitic fluid increased and decreased with that of the serum (Figure 5). There was a 3 -fold increase in the rate of transfer of albumin from the plasma to the ascitic fluid during the period of albumin therapy. The rate of formation of ascites was not decreased.

\section{DISCUSSION}

The aims of the present investigation, as outlined earlier, were (1) to determine whether the formation of ascites is controlled by osmotic forces, and (2) to evaluate the role of protein diffusion from the plasma into the ascitic fluid. The ex- 
perimental results may be interpreted to throw light upon these problems.

\section{Osmotic equilibrium between the plasma and the ascitic fluid}

The experimental data suggest that approximate osmotic equilibrium exists between the plasma and the ascitic fluid. In each patient there was a constant difference between the colloid osmotic pressures of the plasma and ascitic fluid. Experimental disturbance of this relation altered the rates of fluid and protein transfer in directions tending to reestablish the previous colloid osmotic pressure difference. It may be postulated that this constancy of the colloid osmotic pressure difference (plasma colloid osmotic pressure minus ascitic colloid osmotic pressure) is maintained through osmotic equilibrium with a constant net hydrostatic force (portal capillary pressure minus intra-abdominal hydrostatic pressure) in accordance with the Starling equilibrium equation. The effective portal pressure in each patient may be assumed to depend upon the degree of intrahepatic portal obstruction.

As a corollary to this hypothesis, the possibility suggested itself that measurements of the colloid osmotic pressure difference between the plasma and ascitic fluid might serve as an index to the relative portal venous pressure. Preliminary comparisons of such measurements in patients with cirrhosis of the liver, portal venous thrombosis, chronic glomerulonephritis in the nephrotic phase, and peritoneal carcinomatosis tend to support this view (Table I), but comparisons with direct

TABLE I

Colloid osmotic pressure differences between serum and ascitic fluid in various diseases: Correlation with expected degree of portal obstruction

\begin{tabular}{|c|c|c|}
\hline Disease & $\begin{array}{l}\text { Serum } \\
\text { C.O.P. }\end{array}$ & $\begin{array}{l}\text { Serum C.O.P. } \\
\text { minus ascitic } \\
\text { C.O.P. }\end{array}$ \\
\hline $\begin{array}{l}\text { Laennec's cirrhosis } \\
\text { (14 cases) }\end{array}$ & $\begin{array}{l}m m \cdot \mathrm{H}_{2} \mathrm{O} \\
180-317\end{array}$ & $\begin{array}{c}m m . H_{2} O \\
175 \pm 30 \mathrm{~mm} .\end{array}$ \\
\hline $\begin{array}{l}\text { Portal venous thrombosis } \\
\text { (1 case) }\end{array}$ & $275-295$ & $244 \pm 5 \mathrm{~mm}$ \\
\hline $\begin{array}{l}\text { Chronic glomerulonephritis in } \\
\text { nephrotic phase } \\
\text { ( } 2 \text { cases) }\end{array}$ & $87-129$ & $86 \pm 6 \mathrm{~mm}$ \\
\hline $\begin{array}{ll}\text { Peritoneal tumors } & \\
\text { Ovarian carc.: } & 1 \\
\text { Breast carc.: } & 1 \\
\text { Lymphosarcoma: } & 1\end{array}$ & $242-310$ & $110 \pm 20 \mathrm{~mm}$ \\
\hline
\end{tabular}

measurements of the portal venous pressure at laparotomy are necessary for confirmation.

\section{Diffusion of plasma proteins into the peritoneal cavity}

If the above hypothesis is accepted, that the plasma and ascitic fluid are in osmotic equilibrium, it must follow that transudation into the peritoneal cavity proceeds only by virtue of protein diffusion from the plasma into the ascitic fluid. At a state of true osmotic equilibrium no net transfer of protein or fluid would occur in either direction. But the process of ascites formation may be pictured as one of partial or dynamic equilibrium in the sense that the diffusion of plasma proteins into the ascitic fluid, which would tend to increase the colloid osmotic pressure of the ascitic fluid, is balanced by fluid adjustments sufficiently rapid to maintain osmotic equilibrium. In support of such a concept are the observations of Loeb, Atchley, and Palmer (27), Van Slyke, Wu, and McLean (28), and of Hastings and his co-workers (29), that the electrolyte distribution ratios between the plasma and the ascitic fluid are in accord with the Gibbs-Donnan law $(30,31)$ governing osmotic equilibrium between solutions of unequal protein concentration.

The influence of protein diffusion into the ascitic fluid is illustrated in 2 experiments described above. The effects of mercupurin diuresis and of intravenous injection of concentrated albumin are similar in that (1) the plasma colloid osmotic pressure is increased in both instances, and (2) the ascitic colloid osmotic pressure tends to increase parallel with that of the plasma. However, in the former experiment, the increase of ascitic colloid osmotic pressure is apparently effected by absorption of fluid from the peritoneal cavity, while, in the latter, there occurs instead an increased diffusion of albumin from plasma to ascitic fluid.

This increased diffusion of albumin into the ascitic fluid following intravenous injection of albumin may be correlated with the observed increase in plasma volume (10). Previous workers have shown that (a) experimental elevation of blood volume produces increased portal venous pressure ( 1 , and $(b)$ experimental venous congestion produces increased diffusion of plasma proteins through the capillary walls (16). Accord- 
ingly, the injection of concentrated albumin may be pictured as having 2 competing effects: (1) elevation of the plasma colloid osmotic pressure, which would tend to withdraw fluid from the peritoneal cavity, and (2) increase of the plasma volume (by rapid absorption of fluid from the interstitial spaces), which would tend to increase the portal capillary pressure and thus increase the rate of diffusion of albumin into the ascitic fluid. The net effect in a given patient might be expected to depend upon $(a)$ the permeability of the portal capillaries, $(b)$ the renal response to an increase of plasma volume (10), and (c) the amount of albumin injected.

\section{The mechanism of ascites formation}

The pathogenesis of ascites in patients with cirrhosis of the liver has not been revealed in the present studies. It would appear that ascites formation is the result of a combination of factors: increased portal capillary pressure, decreased plasma colloid osmotic pressure, and increased diffusion of protein through the walls of the portal capillaries. These in turn may be influenced by such factors as: increased plasma volume $(10,32)$, electrolyte changes, and antidiuretic substances $(9,10)$. The relationships among these several factors need further study.

\section{SUM MARY}

Osmotic factors influencing the formation of ascites were studied in 10 patients with cirrhosis of the liver. The colloid osmotic pressure of serum and ascitic fluid, the intraperitoneal hydrostatic pressure, and ascitic volume were measured (a) during the unmodified course of formation and loss of ascites, and (b) following experimental alteration of the colloid osmotic pressure of the plasma or ascitic fluid.

1. In the unmodified course of formation and loss of ascites, changes in serum colloid osmotic pressure were accompanied by parallel changes in ascitic colloid osmotic pressure, so that the difference between the colloid osmotic pressures of the serum and ascitic fluid was approximately constant in each patient through periods of 4 months to 1 year.

2. The accumulation of ascites between abdominal paracenteses was associated with a nearly 2- fold increase in the mean intraperitoneal hydrostatic pressure. Except for a brief period immediately following paracentesis, the ascitic volume increased at a uniform rate. The colloid osmotic pressures of the serum and ascitic fluid remained constant.

3. Increase of the colloid osmotic pressure of the plasma following mercupurin diuresis was associated with: (a) absorption of fluid from the peritoneal cavity, and $(b)$ increase of the colloid osmotic pressure of the ascitic fluid.

4. Decrease of the colloid osmotic pressure of the plasma following the oral administration of isotonic sodium chloride solution was associated with: (a) increased transudation into the peritoneal cavity, and $(b)$ decrease of the colloid osmotic pressure of the ascitic fluid.

5. Decrease of the colloid osmotic pressure of the ascitic fluid by the intraperitoneal injection of isotonic sodium chloride solution was followed by: (a) a slight decrease in the rate of ascites formation, (b) increased diffusion of plasma proteins into the ascitic fluid, and (c) decrease of the plasma colloid osmotic pressure.

6. Increase of the colloid osmotic pressure of the plasma by the intravenous injection of concentrated human serum albumin in 3 patients did not result in absorption of fluid from the peritoneal cavity. The effects were: (a) a 3-fold increase in the rate of transfer of albumin from the plasma into the ascitic fluid, and $(b)$ increase of the colloid osmotic pressure of the ascitic fluid parallel with that of the plasma.

7. In each instance, the changes in the rates of fluid and protein exchange tended to restore the preexisting constant difference between the colloid osmotic pressures of the plasma and ascitic fluid.

\section{CONCLUSIONS}

1. Approximate osmotic equilibrium exists between the plasma and the ascitic fluid during unmodified formation and loss of ascites.

2. The flow of fluid between the plasma and ascitic fluid is influenced by experimental disturbance of the osmotic balance, in accordance with the Starling hypothesis.

3. The diffusion of plasma protein into the ascitic fluid is an important factor influencing the 
formation of ascites, both in the unmodified course and after experimental alteration of the osmotic balance.

\section{ACKNOWLEDGMENTS}

The authors are indebted to Dr. Arthur J. Patek, Jr. and Dr. Forrest E. Kendall for their advice and encouragement throughout the course of this work, and to Mr. Walter Meyer for technical assistance.

\section{BIBLIOGRAPHY}

1. Bayliss, W. M., and Starling, E. H., Observations on venous pressures and their relationship to capillary pressures. J. Physiology, 1894, 16, 159.

2. Starling, E. H., The influence of mechanical factors on lymph production. J. Physiology, 1894, 16, 224.

3. Starling, E. H., On the absorption of fluids from the connective tissue spaces. J. Physiology, 1895, 19, 312.

4. Blakemore, A. H., Portocaval anastomosis: a report on fourteen cases. Bull. N. Y. Acad. Med., 1946, 22, 254.

5. Peters, J. P., and Eisenman, A. J., Serum proteins in diseases not primarily affecting the cardiovascular system or kidneys. Am. J. M. Sc., 1933, 186, 808.

6. Myers, W. K., and Keefer, C. S., Relation of plasma proteins to ascites and edema in cirrhosis of the liver. Arch. Int. Med., 1935, 55, 349.

7. Post, J., and Patek, A. J., Jr., Serum proteins in cirrhosis of the liver. Arch. Int. Med., 1942, 69, 67.

8. Butt, H. R., Snell, A. M., and Keys, A., Plasma protein in hepatic disease; a study of the colloid osmotic pressure of blood serum and of ascitic fluid in various diseases of the liver. Arch. Int. Med., 1939, 63, 143.

9. Ralli, E. P., Robson, J. S., Clarke, D., and Hoagland, C. L., Factors influencing ascites in patients with cirrhosis of the liver. J. Clin. Invest., 1945, 24, 316.

10. Patek, A. J., Jr., Mankin, H., Colcher, H., Lowell, A., and Earle, D. P., Jr., The effects of intravenous injection of concentrated human serum albumin upon blood plasma, ascites, and renal function in three patients with cirrhosis of the liver. J. Clin. Invest., 1948, 27, 135.

11. Starling, E. H., The fluids of the body. The Herter Lectures (New York 1908). W. T. Keener and Co., Chicago, 1909.

12. Patek, A. J., Jr., and Post, J., Treatment of cirrhosis of the liver by a nutritious diet and supplements rich in vitamin B complex. J. Clin. Invest., 1941, 20, 481.

13. Hepp, O., Ein neues Onkometer zur Bestimmung des kolloidosmotischen Druckes mit gesteigerter Messgenauigkeit und vereinfachter Handhabung. Ztschr. f. d. ges. exp. Med., 1936, 99, 709; Uber den Einfluss der Temperatur und der Kahlensaurespannung auf den kolloidosmotischen Druck von Serum und Blut. Ztschr. f. Biol., 1938, 99, 230.

14. Pierce, H. F., Nitrocellulose membranes of graded permeability. J. Biol. Chem., 1927, 75, 795.

15. Peters, J. P., Eisenman, A. J., and Bulger, H. A., The plasma proteins in relation to blood hydration. 1. In normal individuals and in miscellaneous conditions. J. Clin. Invest., 1925, 1, 435.

16. Landis, E. M., Jonas, L., Angevine, M., and Erb, W., The passage of fluid and protein through the human capillary wall during venous congestion. J. Clin. Invest., 1932, 11, 717.

17. Thompson, W. O., Thompson, P. K., and Dailey, E., The effect of posture upon the composition and volume of the blood in man. J. Clin. Invest., 1928, 5,573

18. Krogh, A., Landis, E. M., and Turner, A. H., The movement of fluid through the human capillary wall in relation to venous pressure and to the colloid osmotic pressure of the blood. J. Clin. Invest., 1932, 11, 63.

19. Youmans, J. B., Wells, H. S., Donley, D., and Miller, D. G., The effect of posture (standing) on the serum protein concentration and colloid osmotic pressure of blood from the foot in relation to the formation of edema. J. Clin. Invest., 1934, 13, 447.

20. Gibson, J. G., II, and Evans, W. A., Jr., Clinical studies of the blood volume. 1. Clinical application of a method employing the azo dye "Evans blue" and the spectrophotometer. J. Clin. Invest., 1937, 16, 301.

21. Meyer, P., Untersuchungen über den kolloidosmotischen Druck des Blutes. 1. Oedema und Oedemauschwemmung. Ztschr. f. klin. Med., 1931, 115, 647. II. Die Salyrgandiurese. Ibid., 1931, 116, 174.

22. DeVries, A., Changes in hemoglobin and total plasma protein after injection of mercurophylline. Arch. Int. Med., 1946, 78, 181.

23. Kylin, E., Studien über den kolloidosmotischen Druck. XVIII. Über die Einwerkung verschiedener Diuretika auf den kolloidosmotischen Druck. Arch. Exp. Path. Pharmakol., 1932, 164, 33.

24. Blumgart, H. L., Gilligan, D. R., Levy, R. C., Brown, M. G., and Volk, M. C., Action of diuretic drugs. I. Action of diuretics in normal persons. Arch. Int. Med., 1934, 54, 40.

25. Gilligan, D. R., Altschule, M. D., and Volk, M. C., The effects on the cardiovascular system of fluids administered intravenously in man. I. Studies of the amount and duration of changes in blood volume. J. Clin. Invest., 1938, $17,7$.

26. Stewart, J. D., and Rourke, G. M., The effects of large intravenous infusions on body fluid. J. Clin. Invest., 1942, 21, 197. 
27. Loeb, R. F., Atchley, D. W., and Palmer, W. W., On the equilibrium condition between blood serum and serous cavity fluids. J. Gen. Physiol., 1922, 4, 591.

28. Van Slyke, D. D., Wu, H., and McLean, F. C., Studies of gas and electrolyte equilibria in the blood. V. Factors controlling the electrolyte and water distribution in the blood. J. Biol. Chem., 1923, 56, 765.

29. Hastings, A. B., Salvesen, H. A., Sendroy, J., Jr., and Van Slyke, D. D., Studies of gas and electrolyte equilibria in the blood. IX. The distribution of electrolytes between transudates and serum. J. Gen. Physiol., 1927, 8, 701.

30. Gibbs, J. W., On the equilibrium of heterogeneous substances. Trans. Conn. Acad. Arts and Sci., 1876, 3, 108.

31. Donnan, F. G., and Allmand, A. J., Ionic equilibria across semi-permeable membranes. J. Chem. Soc., 1914, 105, 1941.

32. Perera, G. A., The plasma volume in Laennec's cirrhosis of the liver. Ann. Int. Med., 1946, 24, 643. 